\title{
Modified Atmosphere Storage of Minimally Processed Cantaloupe (Cucumis melo L. var. Reticulatus cv. Glamour)
}

\author{
Syahidah Kamaruddin ${ }^{1}$, Rosnah Shamsudin ${ }^{1}$, Noranizan Mohd Adzahan ${ }^{2}$, Zaulia Othman $^{3}$ \& Anvarjon Ahmedov ${ }^{1}$ \\ ${ }^{1}$ Department of Process \& Food Engineering, Faculty of Engineering, University Putra Malaysia, Malaysia \\ ${ }^{2}$ Department of Food Technology, Faculty of Food Science and Technology, University Putra Malaysia, Malaysia \\ ${ }^{3}$ Horticulture Research Centre, Persiaran MARDI-UPM, Malaysia \\ Correspondence: Rosnah Shamsudin, Department of Process \& Food Engineering, Faculty of Engineering, \\ University Putra Malaysia, Malaysia. E-mail: rosnahs@upm.edu.my
}

Received: April 24, 2014 Accepted: July 14, 2014 Online Published: September 15, 2014

doi:10.5539/jas.v6n10p218 URL: http://dx.doi.org/10.5539/jas.v6n10p218

\begin{abstract}
Cantaloupe (Cucumis melo L. var. Glamour) is a type of melon which is characterised by its netted surface. This study was conducted to determine the effects of different sealed packaging materials on the changes in quality of fresh-cut Cantaloupe during storage at $2{ }^{\circ} \mathrm{C}$ and $87 \%$ RH for 18 days. The selection of packaging materials is critical to the development of a modified environment inside the package. The fresh-Cut Cantaloupe fruits (Cucumis melo L. var. Glamour) were packed in Polypropylene (PP) containers and sealed with $40 \mu \mathrm{m}$ Low-Density Polyethylene (LDPE) films and Polypropylene (PP) films. For the control sample, a Polypropylene (PP) container was closed using a lid cover (PP) without a sealing film. Sample 1 (S1) consisted of a Polypropylene (PP) container sealed only with a $40 \mu \mathrm{m}$ PP film and Sample 2 (S2) comprised of a Polypropylene (PP) container sealed with a $40 \mu \mathrm{m}$ LDPE film. The samples were analysed after storage at $2{ }^{\circ} \mathrm{C}$ for 18 days. The Cantaloupe fruits were cut into small cubes of $2 \mathrm{~cm} \times 2 \mathrm{~cm} \times 2 \mathrm{~cm}$. Evaluation parameters include colour, firmness, respiration rate, Total Plate Count (TPC) and Yeast and Mould (YM). Overall for both packages the results indicated that the respiration rate, firmness, Total Plate Count (TPC) and Yeast and Mould (YM) decreased significantly $(\mathrm{p}<0.05$ ), while colour (luminosity, hue angle and chromaticity) were not significantly $(p>0.05)$ different. Samples from the packages sealed with LDPE (S2) indicated better appearance and quality.Thus, LDPE is recommended to be used for packaging of fresh-cut Cantaloupe.
\end{abstract}

Keywords: sealed packaging material, low-density polyethylene (LDPE), polypropylene (PP), quality, respiration rate

\section{Introduction}

Cantaloupe is known as Rockmelon in Malaysia. The word 'Cantaloupe' is commonly used in America to describe the muskmelon or netted melon (Boynton, 2004). Cantaloupe is the fourth largest produced fruit behind grapes, bananas and oranges (Boynton, 2004). Fresh-Cut Cantaloupe is appreciated for its juiciness, flavour and taste. However, the product becomes easily perishable because it involves cutting, slicing and trimming the fruits, which causes deterioration of the tissue (James \& Ngarmsak, 2010). The shelf life and quality of the fresh-cut fruits are affected by storage temperature and packaging conditions as well as the maturity stage (Soliva-Fortuny \& Martín-Belloso, 2003).

The shelf life of fresh cut products depends very much on the type of packaging and storage temperature (Zaulia, 2006). Munira et al. (2013) reported that the post cutting life of fresh-cut Cantaloupe can be stored for three weeks at $2{ }^{\circ} \mathrm{C}$ with better maintenance of product quality. The preparation of fresh-cut products causes plant tissue to deteriorate and shortens the shelf life compared to intact fruits (Watada et al., 1996). This problem arises because the respiration rate is high and also due to damage from the cutting process (Pirovani, 1997). According to Bai et al. (2001) suitable film selection is vital for reaching a gas mixture in MAP that will maintain the quality and inhibit microbial growth.

Usually, the permeability characteristic of packaging containers and lids results in modification in the internal headspace gas concentration throughout the storage time, and it will affect the quality attributes of the fresh-cut fruits (Montero-Calderón et al., 2008). Selection of packaging film materials play an important role in 
developing modified atmosphere packages to improve the quality (Kim et al., 2004). The levels of $\mathrm{O}_{2}$ and $\mathrm{CO}_{2}$ within the package depend on the interaction of the permeability properties of the packaging film (Kader, 1997). The most common food packaging used in Malaysia for fresh cut products are Polypropylene (PP) and Low-Density Polyethylene (LDPE) materials. The objective of this study is to determine the effects of different sealed packaging materials which are Polypropylene (PP) and Low-Density Polyethylene (LDPE) on the changes in the quality (colour, firmness, respiration rate, Total Plate Count (TPC) and Yeast and Mould (YM)) of Fresh-Cut Cantaloupe during storage at $2{ }^{\circ} \mathrm{C}$ and $87 \%$ RH for 18 days.

\section{Material and Method}

\subsection{Sample Preparation and Packaging}

Cantaloupe melons (Cucumis melo L. var. Reticulatus) cultivar Glamour were purchased from a commercial grower farm, Selangor at maturity of 3/4 of full slip and were transported to the Laboratory and stored at the optimum temperature of $10{ }^{\circ} \mathrm{C}$ and $90 \% \mathrm{RH}$ for 48 hours. Fruits were selected based on uniform sizes, defect-free and full netted. The fruits were placed in a cold room, at $10^{\circ} \mathrm{C}$. The outer skin of the cantaloupe was washed with Hydrogen Peroxide $\left(\mathrm{H}_{2} \mathrm{O}_{2}\right)$ then rinsed with tap water to remove dirt and then, dripped dry. Next, the skin of the fruits was peeled with a sharp knife and immersed with deionized water to avoid contamination. All the utensils used were sanitized with Sodium Hypochlorite $(\mathrm{NaOCl})$ solution. Sharp knives were used to reduce flesh wounding (Portela \& Cantwell, 2001; Aguayo et al., 2003; Zainal Abidin et al., 2013). The halved melons were then cut into eight wedge size parts, each of similar size of 4 cube-shaped melons, approximately $(2.0 \times 2.0 \times 2.0 \mathrm{~cm})$, were obtained from each wedge. After that, fresh-cut Cantaloupe was dipped into $1 \%$ calcium lactate for $1 \mathrm{~min}$ for maintaining the product firmness (Zainal Abidin et al., 2013). Sample 1, the container was sealed with $40 \mu \mathrm{m}$ PP (Polypropylene) film and for sample 2, the container was sealed with $40 \mu \mathrm{m}$ LDPE (Low-Density Polyethylene) film. For control samples, container was covered with a lid cover (PP) without sealing any film. The volume of the container is $(350 \mathrm{ml}, 12 \mathrm{oz})$. The films were sealed by using a sealer machine (WY-802D, Guangzhou Verly, China) with the temperature of $130{ }^{\circ} \mathrm{C}-150{ }^{\circ} \mathrm{C}$. Each of the containers contained 9 pieces of fruits $(300 \mathrm{~g} \pm 0.1 \mathrm{~g}$ per piece), therefore it was assumed that the weight of the fruits was constant for all the containers. Then, the samples were stored at temperature of $2{ }^{\circ} \mathrm{C}$ and $87 \%$ of $\mathrm{RH}$. The analysis included headspace composition, texture and colour. Analyses were carried out in 0, 4, 7, 11, 14, and 18 days.

\subsection{Gas Measurement}

The gases in the packages $\left(\mathrm{CO}_{2}\right.$ and $\left.\mathrm{C}_{2} \mathrm{H}_{4}\right)$ were measured using a Gas Chromatograph (GC). A sample of $1 \mathrm{~mL}$ $\mathrm{C}_{2} \mathrm{H}_{4}$ gas was injected into a Perkin Elmer Autosystem, Connecticut, USA, fitted with a flame ionisation detector (FID) and a stainless steel column packed with "Porapak T" of 100/120 mesh size. The flow rate of the purified helium gas was $30 \mathrm{ml} / \mathrm{min}$ and the column oven was operated at $50{ }^{\circ} \mathrm{C}$ and $100{ }^{\circ} \mathrm{C}$ for the $\mathrm{CO}_{2}$ and $\mathrm{C}_{2} \mathrm{H}_{4}$ gases. Helium was used as a carrier gas. Three replications were used for each measurement and the average was taken to produce a single value.

\subsection{Texture Analysis}

Flesh texture was determined using a TA.XTPlus Texture Analyser (Stable Micro Systems, Surrey, UK) equipped with a $5 \mathrm{~mm}$ diameter cylindrical probe. A $5 \mathrm{~kg}$ load was used for texture data. A two-cycle compression test was performed with the following settings: preset speed, $2 \mathrm{~mm} / \mathrm{s}$; test speed $1 \mathrm{~mm} / \mathrm{s}$; post-test speed $2 \mathrm{~mm} / \mathrm{s}$; distance as $30 \%$ strain; time $1 \mathrm{~s}$; trigger force $20 \mathrm{~g}$ (Laminkara \& Watson,2007; Zainal Abidin et al., 2013). The result was recorded as the maximum load in Newtons (N). The results of three replications were averaged to acquire a single value.

\subsection{Colour}

Colour measurement was performed by using a colour reader (CR 10 Tristimulus Colorimeter Konica Minolta, Japan). The equipment simply measures the colour of the target. After one second, the colour difference was expressed as $\mathrm{L}^{*} \mathrm{a}^{*} \mathrm{~b} *$ or $\mathrm{L}^{*} \mathrm{C}^{*} \mathrm{H}^{*}$. Three melon cubes from each of the three containers were measured on every each of the evaluation day. The luminosity $\left(\mathrm{L}^{*}\right)$ values were recorded while chromaticity $\mathrm{C}^{*}=\left[\left(\mathrm{a}^{*}\right)^{2}+\left(\mathrm{b}^{*}\right)^{2}\right]^{0.5}$ and hue angle $h_{a b}=\tan ^{-1}\left[\left(b^{*}\right) \times\left(a^{*}\right)^{-1}\right]$, where $a^{*}$ represents sample greenness and $b^{*}$ is yellowness, were calculated according to the appropriate formula (Machado et al., 2008; Zainal Abidin et al., 2013).

\subsection{Microbiological Analysis}

Microbiological growth in the melon cubes was observed as the total plate count (TPC) and yeast and mould (YM) counts. The following method was applied according to Luna-Guzmán and Barrett (2000). From each replicate, three random melon cubes of $10 \mathrm{~g}$ were collected using sterile techniques from the selected polypropylene container and homogenised (Stomacher, Seward 400, United Kingdom) with $90 \mathrm{ml}$ of sterile 
Ringer solution (Oxoid, Basingstoke Hampshire, England) in a sterile stomacher bag (Labchem Technology Centre, Malaysia) for 1 minute. Serial dilutions required for sample plating were prepared in $9 \mathrm{ml}$ of ringer solution. The pour plate method was performed using the following media and culture conditions: Plate Count Agar (Difco, Becton Dickinson Company, France) for TPC and Potato Dextrose Agar (Difco, Becton Dickinson Company, France) for yeast and mould counts with added 10\% tartaric acid (Systerm, Malaysia) to attain a pH of 3.5. Both the media for the TPC and the yeast and mould count were incubated at $35 \pm 2{ }^{\circ} \mathrm{C}$ for 48 hours and $25 \pm 2{ }^{\circ} \mathrm{C}$ for 5 days, respectively. The microbial counts were expressed as $\log 10\left(\mathrm{cfu} \mathrm{g}^{-1}\right)$.

\subsection{Statistical Analysis}

The experiment was conducted using a completely randomised design of three replicates per treatment. SAS 9.2 system (SAS Institute Inc., Cary, NC, USA) was used for analyses of the mean, standard error, variance (ANOVA), and least significant difference test $(\mathrm{t}$-test $)(\mathrm{P}<0.05)$ to compare differences among treatments throughout the different storage time.

\section{Results and Discussion}

\subsection{Respiration Rate}

Table 1. Means for Respiration Rate of fresh-cut cantaloupe $\left(2{ }^{\circ} \mathrm{C}\right.$ and $\left.87 \% \mathrm{RH}\right)$ for 18 days

\begin{tabular}{|c|c|c|c|}
\hline Samples & Storage Time (Days) & Carbon Dioxide, $\mathrm{CO}_{2}\left(\mathrm{mg} \mathrm{CO}_{2} \mathrm{~kg}^{-1} \mathrm{~h}^{-1}\right)$ & Ethylene, $\mathrm{C}_{2} \mathrm{H}_{4}(\mathrm{ml} / \mathrm{kg} / \mathrm{h})$ \\
\hline Control & & $2.231 \mathrm{a}$ & $4.375 b$ \\
\hline S1 & 0 & $2.323 \mathrm{a}$ & $4.847 \mathrm{c}$ \\
\hline S2 & & $2.210 \mathrm{~b}$ & $4.966 \mathrm{a}$ \\
\hline Control & & $1.122 \mathrm{a}$ & $2.078 \mathrm{a}$ \\
\hline $\mathrm{S} 1$ & 4 & $1.118 \mathrm{~b}$ & $2.048 \mathrm{~b}$ \\
\hline S2 & & $1.135 \mathrm{c}$ & $2.089 \mathrm{~b}$ \\
\hline Control & & $0.378 \mathrm{a}$ & $2.054 \mathrm{~b}$ \\
\hline S1 & 7 & $0.477 \mathrm{a}$ & $2.141 \mathrm{c}$ \\
\hline S2 & & $0.501 \mathrm{~b}$ & $2.288 \mathrm{a}$ \\
\hline Control & & $0.798 \mathrm{a}$ & $0.543 \mathrm{a}$ \\
\hline S1 & 11 & $0.755 b$ & $1.141 \mathrm{a}$ \\
\hline S2 & & $0.678 \mathrm{c}$ & $0.889 b$ \\
\hline Control & & $0.689 \mathrm{a}$ & $0.876 \mathrm{a}$ \\
\hline $\mathrm{S} 1$ & 14 & $0.750 \mathrm{~b}$ & $0.957 \mathrm{a}$ \\
\hline S2 & & $1.254 \mathrm{c}$ & $0.918 b$ \\
\hline Control & & $0.958 \mathrm{a}$ & $0.576 a$ \\
\hline $\mathrm{S} 1$ & 18 & $0.980 \mathrm{~b}$ & $0.689 a$ \\
\hline S2 & & 1.294 & $0.748 b$ \\
\hline
\end{tabular}

*Means same letter are not significantly different at $\mathrm{P}>0.05$ for each column (Control $=$ lid cover only, $\mathrm{S} 1=40$ $\mu \mathrm{m}$ film lid of PP, S2 $=40 \mu \mathrm{m}$ film lid of LDPE).

\subsection{Respiration Rate}

The gas composition within a package results from a number of factors that include the permeability characteristics of the package and the respiratory behaviour of the fruits within the environment. Changes in respiration during ripening can be reduced by eliminating the ethylene through the use of low level of $\mathrm{C}_{2} \mathrm{H}_{4}$ and high levels of $\mathrm{CO}_{2}$ atmospheres (Mir \& Beaudry, 2000) Table 1 shows the carbon dioxide production by fresh cut cantaloupe during storage for 18 days at $2{ }^{\circ} \mathrm{C}$ and $87 \% \mathrm{RH}$. From Table 1, the production of $\mathrm{CO}_{2}$ was high in the initial state for all the samples. From day 0 to day 18, the average mean values of $\mathrm{CO}_{2}$ were $2.231-0.378$ $\mathrm{ml} / \mathrm{kg} / \mathrm{h}$ (control), $2.323-0.477 \mathrm{ml} / \mathrm{kg} / \mathrm{h}(\mathrm{S} 1)$ and $2.210-0.501 \mathrm{ml} / \mathrm{kg} / \mathrm{h}(\mathrm{S} 2)$. Studies from Soliva-Fortuny and 
Martín-Belloso (2003) reported that a wound response was detected to cause an increase in $\mathrm{CO}_{2}$ production immediately after cutting. From the results, three days after processing, the $\mathrm{CO}_{2}$ declined significantly $(\mathrm{p}<0.05)$ and became stable until day 14. After day 14 until day 18 , the $\mathrm{CO}_{2}$ levels in the control and $\mathrm{S} 1$ treatments remained stable without any significant difference $(\mathrm{p}>0.05)$ but for $\mathrm{S} 2$, the level of $\mathrm{CO}_{2}$ increased. Hence a higher level of $\mathrm{CO}_{2}$ accumulated in $\mathrm{S} 2$.

Table 1 shows the ethylene gas produced by the fresh-cut cantaloupe during storage for 18 days at $2{ }^{\circ} \mathrm{C}$ and $87 \%$ RH. For the control sample, the range mean value of ethylene was $4.375-0.543 \mathrm{ml} / \mathrm{kg} / \mathrm{h}$ meanwhile the other samples recorded $4.847-0.689 \mathrm{ml} / \mathrm{kg} / \mathrm{h}(\mathrm{S} 1)$ and $4.966-0.748 \mathrm{ml} / \mathrm{kg} / \mathrm{h}$ (S2) throughout the 18 days of storage. Ethylene levels were very high at day 0 for all samples. However, after day 4, all samples decreased significantly at $(p<0.05)$. The increased rate of ethylene production promoted the deterioration of the fresh-cut Cantaloupe. The atmosphere within the control, S1 and S2 samples did not have any effect on the cubes. The ineffectiveness of the treatments is due to the lower temperature, which was maintained at $2{ }^{\circ} \mathrm{C}$ (Bai et al., 2001). An appropriate combination of package dimensions, gas composition and permeability is critical to reach a sustainable equilibrium of gas composition (Rojas-Grau et al., 2009). This equilibrium must ensure that the $\mathrm{O}_{2}$ level inside the packages is enough to avoid anaerobic fermentative processes (Marti'n-Belloso et al., 2007).

\subsection{Texture}



Figure 2. Firmness $(\mathrm{N})$ of fresh-cut Cantaloupe $\left(2{ }^{\circ} \mathrm{C}\right.$ and $\left.87 \% \mathrm{RH}\right)$ for 18 days (Control= hard lid cover only, $\mathrm{S} 1$ $=40 \mu \mathrm{m}$ film lid of PP, $\mathrm{S} 2=40 \mu \mathrm{m}$ film lid of LDPE)

Tissue softening is a major problem with fresh-cut fruit products that limit its the shelf life (Beaulieu \& Gorny, 2001) Figure 2 shows the firmness (N) of fresh-cut cantaloupe during storage at $2{ }^{\circ} \mathrm{C}$ and $87 \% \mathrm{RH}$ for 18 days of storage. The initial value of firmness for all the samples was approximately $11 \mathrm{~N}-12 \mathrm{~N}$. It was found that the firmness of all the samples decreased throughout the 18 days of storage. The firmness of the fresh-cut Cantaloupe decreased from an initial firmness with total mean decrease of 31.8\% (control), 28\% (S1) and 29\% (S2) of samples, during the 18 days of storage. The textural changes of the fresh cut cantaloupe took place due to cutting the plant tissue, which increased the respiration rate and which in turn induced the production of ethylene, and was responsible for the major tissue disruption (Toivonen \& De-Ell, 2002). No significant difference was found among the samples. Previous studies conducted by Bai et al. (2001) indicated that no significant difference was found between the MAP treatments tested and the control. 


\subsection{Colour}

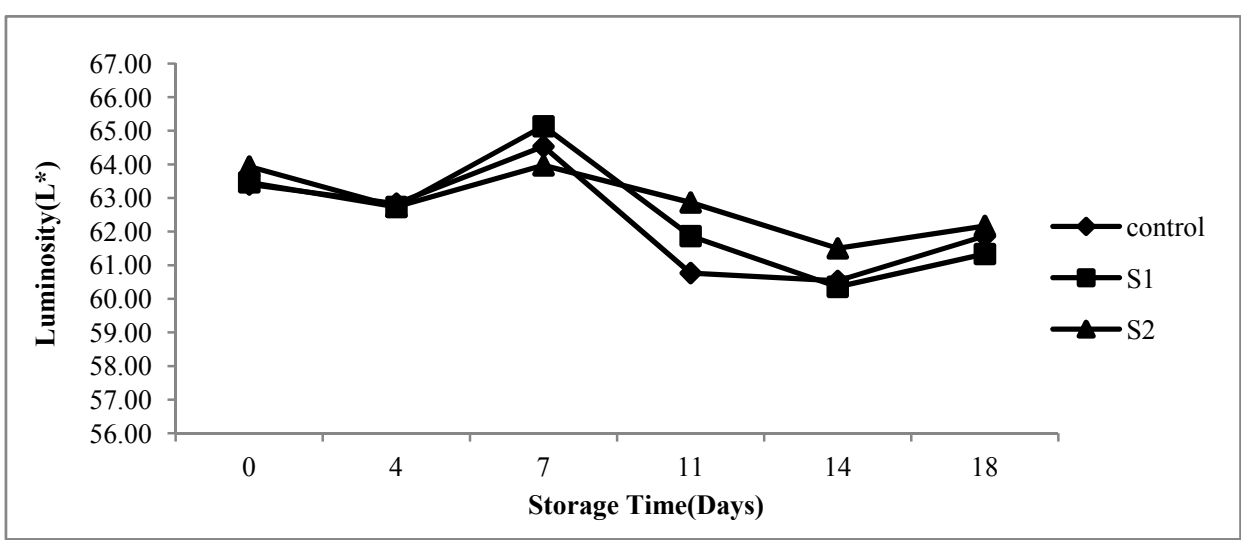

Figure 3. Luminosity $\left(\mathrm{L}^{*}\right)$ of fresh-cut Cantaloupe $\left(2{ }^{\circ} \mathrm{C}\right.$ and $\left.87 \% \mathrm{RH}\right)$ for 18 days (Control $=$ lid cover only, $\mathrm{S} 1$ $=40 \mu \mathrm{m}$ film lid of PP, $\mathrm{S} 2=40 \mu \mathrm{m}$ film lid of LDPE)

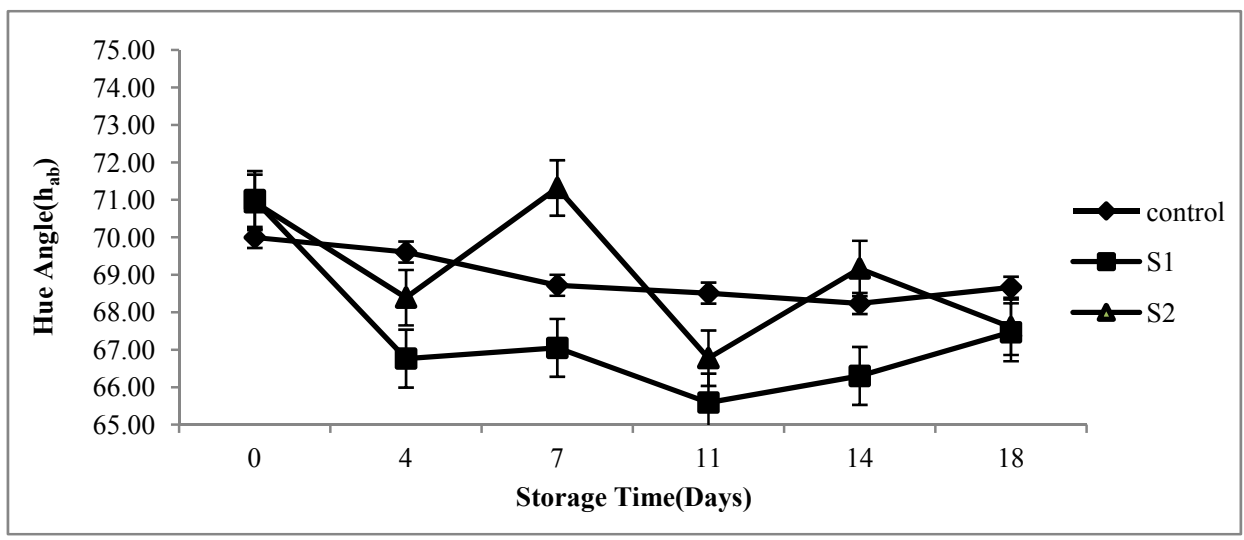

Figure 4. Hue Angle $\left(\mathrm{h}_{\mathrm{ab}}\right)$ of fresh-cut Cantaloupe $\left(2{ }^{\circ} \mathrm{C}\right.$ and $\left.87 \% \mathrm{RH}\right)$ for 18 days (Control $=$ hard lid cover only, $\mathrm{S} 1=40 \mu \mathrm{m}$ film lid of PP, $\mathrm{S} 2=40 \mu \mathrm{m}$ film lid of LDPE)

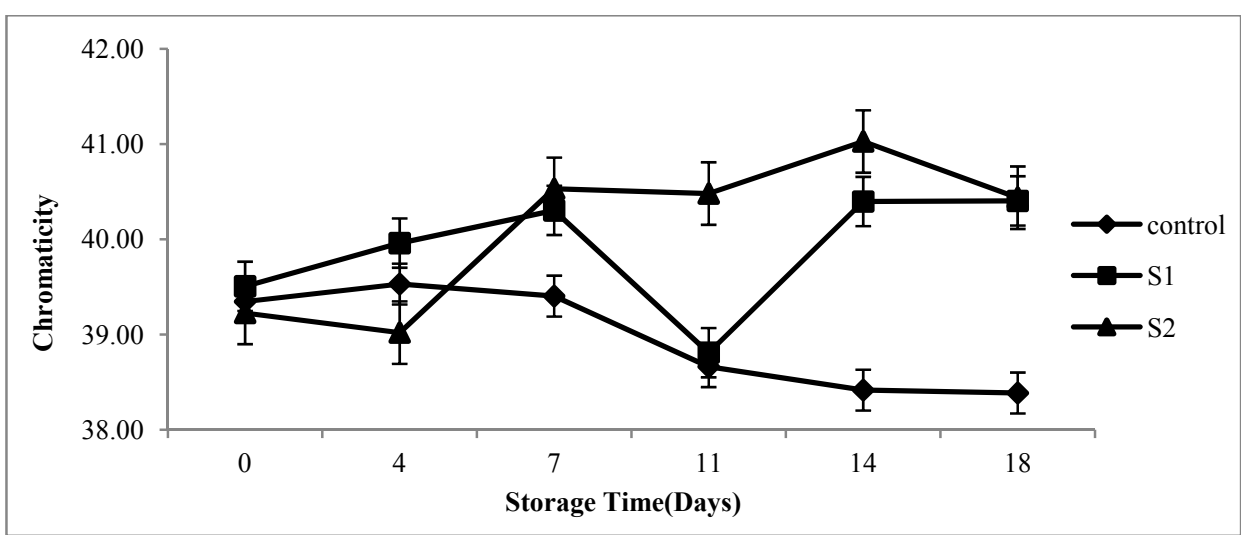

Figure 5. Chromaticity $\left(\mathrm{C}^{*}\right)$ of fresh-cut Cantaloupe $\left(2{ }^{\circ} \mathrm{C}\right.$ and $\left.87 \% \mathrm{RH}\right)$ for 18 days (Control $=$ lid cover only, $\mathrm{S} 1=40 \mu \mathrm{m}$ film lid of PP, S2 $=40 \mu \mathrm{m}$ film lid of LDPE)

Figure 3 shows the Luminosity $\left(\mathrm{L}^{*}\right)$ of the fresh-cut Cantaloupe during the 18 days of storage at $2{ }^{\circ} \mathrm{C}$ and $87 \%$ RH. On day 0 , the three samples had similar values which were approximately 63.00 . On day 4 until day 7 , the 
luminosity increased significantly $(\mathrm{p}<0.05)$. The results show that all of the samples had high brightness due to the maturation pattern of the fruits beginning at the base of the fruits and moving to the top, which shows the different stages of maturity of the fruits (Montero-Calderón et al., 2008). This was not affected by the packaging film. After day 7, the control and S1 samples decreased significantly $(\mathrm{p}<0.05)$. The decrease of the $\mathrm{L}^{*}$ values was related to the development of translucence (Supapvanich \& Tucker, 2011). However, the S2 samples did not decline significantly $(\mathrm{p}>0.05)$. This shows that the LDPE films $(\mathrm{S} 2)$ were useful for the avoidance of discolouration and browning of the fresh-cut Cantaloupe.

Figure 4 shows the hue angle $\left(\mathrm{h}_{\mathrm{ab}}\right)$ of the fresh-cut Cantaloupe during the 18 days of storage at $2{ }^{\circ} \mathrm{C}$. The initial value of all the samples was 70 . The hue angle of the control and S1 were not significantly affected by the packaging film. However, for the S2 samples there was a colour variation throughout the 18 days of storage. The discoloration did not develop on the fresh-cut Cantaloupe for any treatments.

Figure 5 shows the chromaticity of the fresh-cut Cantaloupe during the 18 days of storage at $2{ }^{\circ} \mathrm{C}$. The chroma $\left(C^{*}\right)$ was initially 39 . There was no significant difference as the $C^{*}$ showed the same pattern for all the samples. Maintenance of colour is vital in fresh-cut fruits where the visual appearance is a key factor to encourage the consumer to purchase the products (Zainal Abidin et al., 2013).

\subsection{Microbiological Analysis (TPC and YM)}

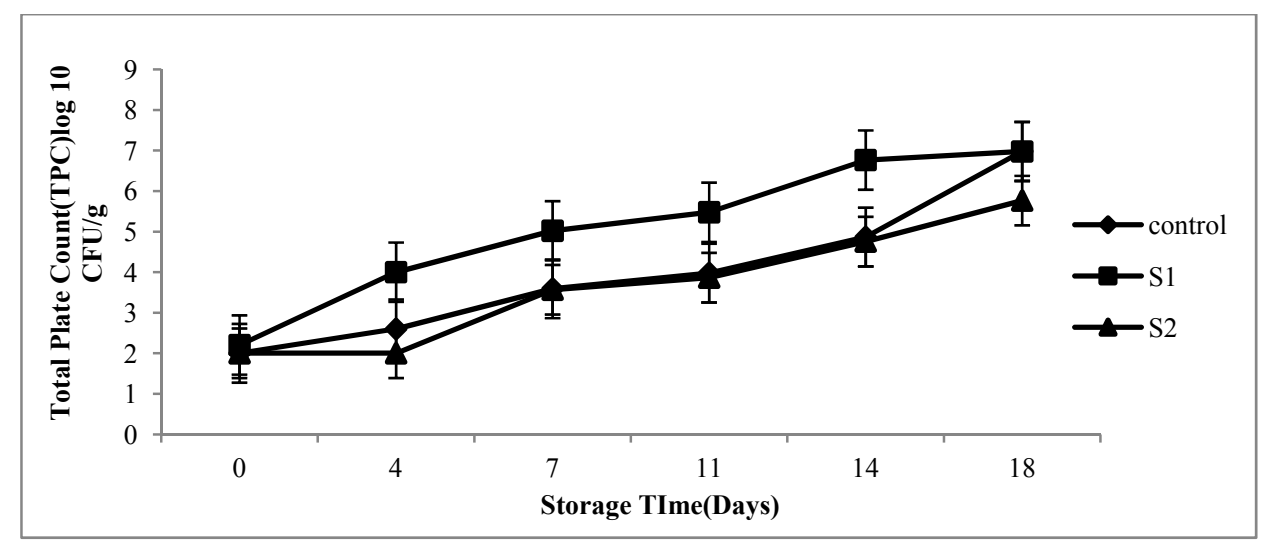

Figure 6. Total Plate Count (TPC) of fresh-cut Cantaloupe $\left(2{ }^{\circ} \mathrm{C}\right.$ and $\left.87 \% \mathrm{RH}\right)$ for 18 days $($ Control $=$ lid cover only, $\mathrm{S} 1=40 \mu \mathrm{m}$ film lid of PP, $\mathrm{S} 2=40 \mu \mathrm{m}$ film lid of LDPE)

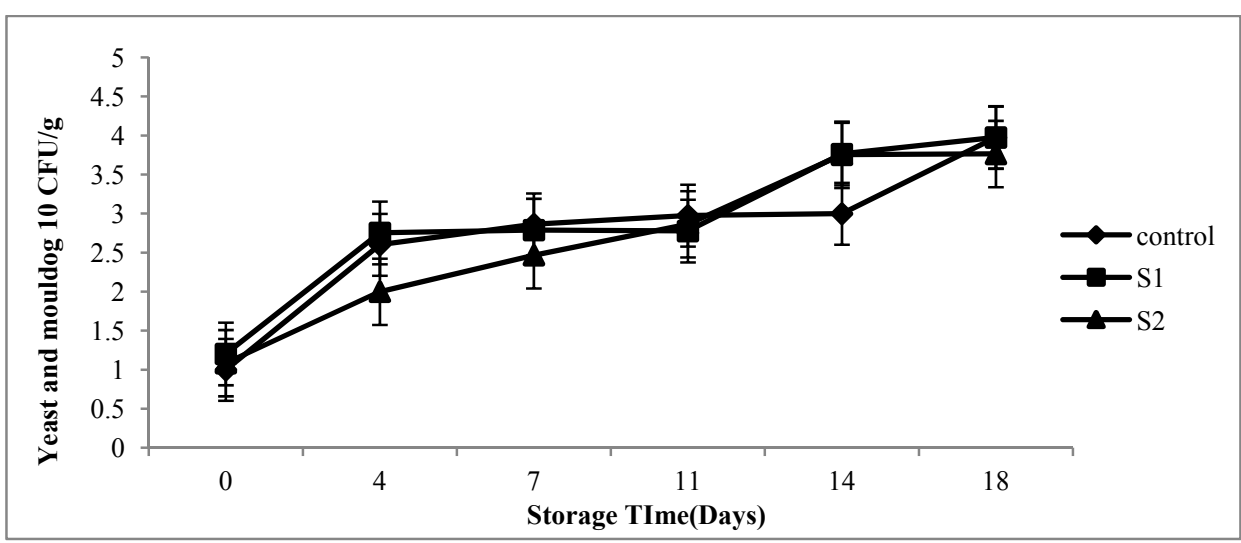

Figure 7. Yeast and Mould (YM) of fresh-cut Cantaloupe $\left(2{ }^{\circ} \mathrm{C}\right.$ and $\left.87 \% \mathrm{RH}\right)$ for 18 days $($ Control $=$ hard lid cover only, $\mathrm{S} 1=40 \mu \mathrm{m}$ film lid of PP, $\mathrm{S} 2=40 \mu \mathrm{m}$ film lid of LDPE)

Microbiological growth can be a major cause of spoilage of fresh-cut products. The infection occurred through cutting and peeling during the fresh-cut processing (Guzmán, 1997). Figure 6 shows the total plate count (TPC) of the fresh-cut cantaloupe during storage at $2{ }^{\circ} \mathrm{C}$ and $87 \%$ RH. For the control, sample 1 and sample 2 , the total 
plate counts increased significantly $(\mathrm{p}<0.05)$ from $2 \log 10 \mathrm{CFU} / \mathrm{g}$ to $6 \log 10 \mathrm{CFU} / \mathrm{g}$ throughout the 18 days of storage. On day 0 , the count of the TPC remained at a low level, approximately $2 \log 10 \mathrm{CFU} / \mathrm{g}$ and after 1 week of storage the mean value of the TPC increased to between $4 \log 10 \mathrm{CFU} / \mathrm{g}$ to $6 \log 10 \mathrm{CFU} / \mathrm{g}$. This shows that the longer the fresh cut is in storage, the higher the possibility of an increase in the bacterial growth. The fresh-cut cantaloupe package with LDPE (S2) film had a lower TPC than the PP (S1) and control. This is due to the lower oxygen and higher carbon dioxide content as shown in the results obtained in Table 1. Low-oxygen atmospheres usually restrain the growth of aerobic microorganisms (Soliva-Fortuny \& Martı'n-Belloso, 2003). The allowable microbial observed in fresh-cut cantaloupe must not exceed $10^{9}$ for consumption (Nguyen-the \& Carlin 1994).

Figure 7 shows the YM (Yeast and Mould) of the fresh-cut cantaloupe during storage at $2{ }^{\circ} \mathrm{C}$ and $87 \% \mathrm{RH}$. The YM counts of the fresh-cut cantaloupe for all the treatments increased significantly $(\mathrm{p}<0.05)$ from $1 \log 10$ $\mathrm{CFU} / \mathrm{g}$ to $3 \log 10 \mathrm{CFU} / \mathrm{g}$ during storage at $2{ }^{\circ} \mathrm{C}$ and $87 \% \mathrm{RH}$ throughout the 18 days of storage. No significant differences were observed for all the treatments on day 4 until day 11. Previous studies have reported that the population of YM remained at a low count (Luna-Guzman \& Barrett, 2000) and some could not be detected during storage (Portela \& Cantwell, 2001). Treatment is important for fresh-cut cantaloupe to retard the growth of microorganisms. From Figure 7, it indicates that the fresh-cut cantaloupes are not harmful for consumption.

\section{Conclusion}

The packaging materials are important to maintain the quality of fresh-cut cantaloupe. From the results, differences among the films used were found. Fresh-cut cantaloupe packed in PP container with a sealed of LDPE film (S2), was found to be suitable and gave better appearance and maintained the quality of the fresh-cut cantaloupe during the 18 days of storage at $2{ }^{\circ} \mathrm{C}$ and $87 \% \mathrm{RH}$. A significant difference occurred in the respiration rate, color, Total Plate Count and Yeast and Mould. However, no significant differences were detected for the firmness for the three kinds of treatment. The use of calcium lactate is strongly recommended to maintain the firmness, avoid discolouration and increase the lightness of the fresh-cut cantaloupe.

\section{References}

Aguayo, E., Allende, A., \& Art, F. (2003). Keeping quality and safety of minimally fresh processed melon. EUR Food Res Technol, 216, 494-499. http://dx.doi.org /10.1007/s00217-003-0682-7

Bai, J. H., Saftner, R. A., Watada, A. E., \& Lee, Y. S. (2001). Modified atmosphere maintains quality of fresh- cut cantaloupe (Cucumis Melo L.). Journal of Food Science, 66, 1207-1211.

Beaulieu, J. C., \& Gorny, J. R. (2001). Fresh-cut fruits. In K. C. Gross, M. E. Saltveit, \& C. Y. Wang (Eds.), The commercial storage of fruits, vegetables, and florist and nursery stocks (pp. 1-49). USDA Handbook, 66.

Boynton, B. B. (2004). Determination of the effects of modified atmosphere packaging and irradiation on sensory characteristics, microbiology, texture and colour of fresh-cut cantaloupe using modelling for package design (Doctoral dissertation). Retrieved from http://etd.fcla.edu/UF/UFE0008326/boynton_b

Guzmán, I. L. (1997). Food Safety and Fresh-Cut Cantaloupe. Perishables Handling Quarterly, 91, 13.

James, J. B., \& Ngarmsak, T. (2010). Processing of fresh-cut tropical fruits and vegetables: A technical guide. Food and Agriculture Organization of the United Nations Regional Office for Asia and the Pacific Bangkok (FAO), Rap Publication. ISBN 978-92-5-106712.

Kader, A. A. (1997). A summary of CA requirements and recommendations for fruits other than apples and pears. In A. Kader (Ed.) Fruits other than apples and pears. Postharvest Horticulture, 17, 1-36.

Kim, J. G., Luo, Y., \& Gross, K. C. (2004). Effect of package film on the quality of fresh-cut salad savoy. Postharvest Biology and Technology, 32, 99-107. http://dx.doi.org/10.1016/j.postharvbio.2003.10.006

Lamikanra, O., \& Watson, M. A. (2007). Mild heat and calcium treatment effects on fresh-cut Cantaloupe melon during storage. Food Chemistry, 102, 1383-1388. http://dx.doi.org/ 10.1016/j. foodchem. 2006.05.060

Luna-Guzman, I., \& Barrett, D. M. (2000). Comparison of calcium chloride and calcium lactate effectiveness in maintaining shelf stability and quality of fresh-cut. Postharvest Biology and Technology, 19, 61-72. http://dx.doi.org/10.1016/S0925-5214(00)00079-X

Machado, F. L. C., Alves, R. E., \& Figueiredo, R. W. (2008). Application of 1-methylcyclopropene, calcium chloride and calcium amino acid chelate on fresh-cut cantaloupe muskmelon. Pesq. agropec. bras. Brasília, 43, 569-574. http://dx.doi.org/10.1590/S0100-204X2008000500003

Martin-Belloso, O., Soliva-Fortuny, R., \& Oms-Oliu, G. (2007). Freshcut fruits. In Y. H. Hui (Ed.), Handbook of 
Food Products Manufacturing. Principles, Bakery, Beverages, Cereals, Cheese, Confectionary, Fats, Fruits, and Functional Foods (pp. 879-899). New Jersey, NJ: John Wiley \& Sons, Inc.

Mir, N., \& Beaudry, R. M. (2000). Modified Atmosphere Packaging. Retrieved from http://www.ba.ars.usda.gov/hb66/015map.pdf

Montero-Calderón, M., Rojas-Graü, M. A., \& Martín-Belloso, O. (2008). Effect of packaging conditions on quality and shelf-life of fresh-cut pineapple (Ananas comosus). Postharvest Biology and Technology, 50, 182-189. http://dx.doi.org/10.1016/j.postharvbio.2008.03.014

Nguyen-the, C., \& Carlin, F. (1994). The microbiology of minimally processed fresh fruits and vegetables. Critical Reviews in Food Science and Nutrition, 34, 371-401. http://dx.doi.org/ $10.1080 / 10408399409527668$

Pirovani, M. E., Guemes, D. R., Piagentini, A. M., \& Pentima, J. H. D. (1997). Storage quality of minimally processed cabbage packaged in plastic films. Journal of Food Quality, 20, 381-389.

Portela, S. I., \& Cantwell, M. I. (2001). Cutting blade sharpness affects appearance and other quality attributes of fresh-cut Cantaloupe melon. Journal of Food Science, 66, 1265-1270. http://dx.doi.org/10.1111/j.1365-2621.2001.tb15199.x

Rojas-Graü, M. A., Oms-Oliu, G., Robert Soliva-Fortuny, R., \& Martín-Belloso, O. (2009). The use of packaging techniques to maintain freshness in fresh-cut fruits and vegetables: a review. International Journal of Food Science \& Technology, 44(5), 875-889. http://dx.doi.org/10.1111/j.1365-2621.2009.01911.x

Soliva-Fortuny, R. C., \& Martín-Belloso, O. (2003). New advances in extending shelf-life of fresh-cut fruits: A review. Trends Food Science and Technology, 14, 341-353. http://dx.doi.org/ 10.1016/S0924-2244(03)00054-2

Supapvanich, S., \& Tucker, G. A. (2011). Physicochemical changes in fresh-cut Honeydew melon fruit during storage African. Journal of Agricultural Research, 6(12), 2737-2742. http://dx.doi.org/ 10.5897/AJAR11.146

Toivonen, P. M. A., \& De-Ell, J. R. (2002). Physiology of fresh-cut fruits and vegetables. In O. Lamikanra (Ed.), Fresh-cut fruits and vegetables. Science, technology and market. Boca Raton, FL: CRC Press. http://dx.doi.org/10.1201/9781420031874.ch5

Watada, A. E., Ko, N. P., \& Minott, D. A. (1996). Factors affecting quality of fresh-cut horticultural products. Postharvest Biological Technology, 9, 115-125.

Zainal Abidin, M., Shamsudin, R., Othman, Z., \& Abdul Rahman, R. (2013). Effect of postharvest storage of whole fruit on physico-chemical and microbial changes of fresh-cut cantaloupe (Cucumis melo L. reticulatus cv. Glamour). International Food Research Journal, 20, 501-508.

Zaulia, O., Razali, M., Aminuddin, H., Che Omar, D., Ng, K. H., \& Habsah, M. (2006). Effect of different packagings and storage temperatures on the quality of fresh-cut Red Chilli. Journal Tropical Agricultural and Food Science, 34, 67-76.

\section{Copyrights}

Copyright for this article is retained by the author(s), with first publication rights granted to the journal.

This is an open-access article distributed under the terms and conditions of the Creative Commons Attribution license (http://creativecommons.org/licenses/by/3.0/). 